Tropical Journal of Pharmaceutical Research April 2017; 16 (4): 855-859

ISSN: $1596-5996$ (print); 1596-9827 (electronic)

(C) Pharmacotherapy Group, Faculty of Pharmacy, University of Benin, Benin City, 300001 Nigeria.

All rights reserved.

Available online at http://www.tjpr.org

Original Research Article

http://dx.doi.org/10.4314/tjpr.v16i4.15

\title{
Effect of Achyranthes bidentata Blume extract on carrageenan-induced chronic prostatitis in rats
}

\author{
Hai-yong Ding, Wei-qing Qian, Jun $\mathrm{Xu}^{\star}$ \\ Department of Urology, Huadong Hospital Affiliated to Fudan University, Shanghai 200040, China
}

*For correspondence: Email: xujun133494@163.com; Tel: +86 02162483180

Received: 3 November 2016

Revised accepted: 13 March 2017

\begin{abstract}
Purpose: To investigate the effect of Achyranthes bidentata Blume. Extract (ABBE) on carrageenaninduced chronic prostatitis in rats.

Methods: Experimental chronic non-bacterial prostatitis (CNP) was induced in rats by $1 \%$ carrageenan $(0.1 \mathrm{~mL})$. Prostate index (PI) and prostate specific antigen (PSA) were determined after 3 weeks of adiministration. Relative inflammatory factors, viz, tumor necrosis factor- $\alpha$ (TNF- $\alpha$ ), interleukin $1 \beta$ (IL-1 $\beta$ ), cyclooxygenase-2 (COX-2), prostaglandin E2 (PEG2), transforming growth factor- $\beta 1$ (TGF- $\beta 1$ ) and connective tissue growth factor (CTGF) in the prostate tissues of all group rats were measured.

Results: In CNP model, ABBE decreased PI and PSA compared with untreated control group ( $p<$ 0.01 ). Morphometric analysis showed a significant reduction in chronic inflammatory cell infiltrates and interstitial fibrosis compared to control group. Reduced values of TNF- $\alpha, I L-1 \beta, C O X-2$, PEG2 were observed in ABBE-treated groups compared with model group respectively $(p<0.01)$. Moreover, the levels of TGF- $\beta 1$ and CTGF in ABBE-treated groups were significantly lower, and in addition, there was alleviation of the inflammatory state of the prostate gland $(p<0.01)$.

Conclusion: ABBE showed antichronic non-bacterial prostatitis effect by multiple ways in rats, thus indicating its potential suitability for the treatment of chronic prostatitis.
\end{abstract}

Keywords: Achyranthes bidentata Blume., Chronic prostatitis, Inflammatory cell

Tropical Journal of Pharmaceutical Research is indexed by Science Citation Index (SciSearch), Scopus, International Pharmaceutical Abstract, Chemical Abstracts, Embase, Index Copernicus, EBSCO, African Index Medicus, JournalSeek, Journal Citation Reports/Science Edition, Directory of Open Access Journals (DOAJ), African Journal Online, Bioline International, Open-J-Gate and Pharmacy Abstracts

\section{INTRODUCTION}

Epidemiological research indicates prostatitis is one of the major medical healthcare problems in urology [1]. Prostatitis has been classified into three clinical entities: (I) acute bacterial prostatitis (II) chronic bacterial prostatitis; (III) chronic prostatitis (CP)/chronic pelvic pain syndrome (CPPS) [2]. Category III is further subdivided into category IIIA or inflammatory, and category IIIB or non-inflammatory. Chronic non-bacterial prostatitis (CNP), which belongs to category IIIA, is the most common form of the prostatitis syndromes, approximately eight times more prevalent than bacterial prostatitis [3]. CNP is characterized by chronic, idiopathic pelviperineal pain and an inflammatory subtype with leukocytes expressed in their prostatic secretions [4].

The plant, Achyranthes bidentata Blume., widely distributed in southwest of China, was the main material of traditional Chinese medicine "niuxi", was used as folk medicine for immunemodulation [5], anti-tumor [6] and anti-bacterial $[7,8]$, etc. In this study, we evaluated the effect of 
ABBE against carrageenan-induced chronic nonbacterial prostatitis and its possible mechanisms.

\section{EXPERIMENTAL}

\section{Plant material}

Achyranthes bidentata Blume was collected from Bozhou City, Anhui Province in China in May 2015. Taxonomic identification of the plant was performed by Professor Hui Wang of Fudan University, in China. A voucher specimen (no. ABBE 20150504) was deposited in the herbarium of College of Pharmacy, Fudan University, China for future reference. The aqueous extract of ABBE was obtained by steeping three batches of dried Achyranthes bidentata Blume in water at $60{ }^{\circ} \mathrm{C}$ three times, each for one hour, and then drying the extract in an oven and thereafter freeze-drying it. One gram powder was equivalent to about $1.5 \mathrm{~g}$ crude sample, giving a yield of $66.67 \%$.

\section{Animals}

Eight-week old male Wistar rats $(300-350 \mathrm{~g})$ were provided by the Experimental Animal Center of Shanghai Municipality (certificate no. SYXK 2008-0006). The animals had free access to food and water, and were allowed to acclimatize for at least one week before use. The rat experiment was approved by the Animal Care and Use Committee of Huadong hospital affiliated to Fudan University (approval ref no. 20111013) and was carried out in compliance with Directive 2010/63/EU on the handling of animals used for scientific purposes [9].

\section{Animal groups}

The rats were randomly divided into 6 groups of ten rats each: normal group, negative control group, positive control group (cernilton 100 $\mathrm{mg} / \mathrm{kg}$ ) as well as ABBE groups, namely, 100, 200 and $400 \mathrm{mg} / \mathrm{kg}$ doses. Treatments were given orally once daily for 3 weeks, dissolved in water. The drugs were given into the rats by intragastric administration.

\section{Preparation of carrageenan-induced chronic non-bacterial prostatitis (CNP) model}

CNP model rats were prepared as previously described [10]. Briefly, for sham group, prostates of each rat were injected with $0.1 \mathrm{~mL}$ saline, and the same volume of $1 \%$ carrageenan in model and drug administration groups. Seven days later, rats in drug administration and positive groups were kept for oral administration of ABBE extract or cernilton for 3 weeks, the sham and model groups were given saline at the same time.

\section{Measurement of prostatic index (PI) and prostate specific antigen (PSA)}

The prostatic index $(\mathrm{PI})$ of all rats was measured. $\mathrm{PI}=$ prostate weight $(\mathrm{mg}) /$ body weight $(\mathrm{g})$. The blood sample of rats was get by eyeball removal after the prostates were revoming. The collected serum was separated at $3500 \mathrm{r} / \mathrm{min}$ for $15 \mathrm{~min}$ and used for determination of prostate specific antigen (PSA) by ELISA kits (Shenzhen Xin-BoSheng Biological Technology Co Ltd, China).

\section{Measurement of tumor necrosis factor- $\alpha$ (TNF- $\alpha$ ) and interleukin $1 \beta$ (IL-1 $\beta$ )}

Quantitative measurement of pro-inflammatory cytokines TNF- $\alpha$ and IL- $1 \beta$ was done in the prostate tissue of both CNP and treated groups using commercial ELISA assay kits (Shenzhen Xin-Bo-Sheng Biological Technology Co Ltd, China), according to manufacturer's instruction. The samples and standards were all run in quadruplicate and the data are averaged. The results are expressed as $\mathrm{pg} / \mathrm{mL}$.

\section{Measurement of $\mathrm{PGE}_{2}, \mathrm{COX}-2$, TGF- $\beta 1$ and CTGF}

The effect of CNP on productions of $\mathrm{PGE}_{2}$, COX2 , TGF- $\beta 1$ and CTGF were measured in prostate tissues using commercial ELISA kits (Shenzhen Xin-Bo-Sheng Biological Technology Co Ltd, China). All assays were performed in $10 \%$ prostate supernatant in accordance with manufacturer's instructions. The amounts of $\mathrm{PGE}_{2}, \mathrm{COX}-2, \mathrm{TGF}-\beta 1$ and CTGF in prostate tissue were expressed as $\mathrm{pg} / \mathrm{mL}$.

\section{Statistical analysis}

The data are presented as mean \pm standard deviation (SD), and were analyzed by one-way ANOVA followed by Tukey's multiple comparison using SPSS 16.0 software for Windows. Differences were considered statistically significant at $p<0.05$.

\section{RESULTS}

\section{Effect of ABBE on PI and PSA}

After 3 weeks of administration, the effects of oral administration of ABBE on the levels of PI and PSA are summarized in Table 1. In the model group, the levels of PI and PSA increased to $2.1 \mathrm{mg} / \mathrm{g}$ and $312.5 \mathrm{pg} / \mathrm{mL}$, respectively $(p<$ 0.01 ). By contrast, after treatment with ABBE, 
especially $400 \mathrm{mg} / \mathrm{kg}$, the levels of PI and PSA had dropped significantly $(p<0.01)$.

Table 1: Effect of ABBE on PI and PSA levels (mean $\pm \mathrm{SD}, \mathrm{n}=10$ )

\begin{tabular}{lccl}
\hline Group & $\begin{array}{c}\text { Dose } \\
(\mathbf{m g} / \mathbf{k g})\end{array}$ & $\mathbf{P I}(\mathbf{m g} / \mathbf{g})$ & PSA(pg/mL) \\
\hline Normal & - & $0.8 \pm 0.2^{* *}$ & $123.2 \pm 10.8^{*}$ \\
Negative & - & $2.1 \pm 0.2$ & $312.5 \pm 20.5$ \\
contro & - & $1.5 \pm 0.4$ & $182.7 \pm 16.4^{*}$ \\
Cernilton & 100 & $1.6 \pm 0.3$ & $274.6 \pm 33.5$ \\
PSA-L & 100 & $1.3 \pm 0.2^{*}$ & $180.5 \pm 21.9^{* \pi}$ \\
PSA-M & 200 & $1.0 \pm 0.1^{* \pi}$ & $154.2 \pm 14.3^{* \pi}$ \\
PSA-H & 400 & ${ }^{* *} p<0.01$ vs. model group
\end{tabular}

\section{Effect of ABBE on TNF- $\alpha$ and IL-1 $\beta$}

The TNF- $\alpha$ level of the sham group rats was $100.8 \mathrm{pg} / \mathrm{ml}$. Carrageenan-treatment caused significant increase in the level of TNF- $\alpha$ compared with the sham group $(p<0.01)$. Oral treatment of ABBE extract at doses of $400 \mathrm{mg} / \mathrm{kg}$ resulted in decrease of TNF- $\alpha$ level when compared to model group $(p<0.01)$. The level of IL-1 $\beta$ was significantly increased in model group compared to control group $(p<0.01)$. However, the IL-1 $\beta$ level was significantly decreased to 1 , 17.5 or $97.6 \mathrm{pg} / \mathrm{mL}$ at the dose of 200 and 400 $\mathrm{mg} / \mathrm{kg}$ groups respectively $(p<0.01$, Table 2$)$.

Table 2: Effect of ABBE on TNF- $\alpha$ and IL-1 $\beta$ levels $($ mean $\pm S D, n=10$ )

\begin{tabular}{|c|c|c|c|}
\hline Group & $\begin{array}{c}\text { Dose } \\
(\mathrm{mg} / \mathrm{kg})\end{array}$ & $\begin{array}{c}\text { TNF- } \\
\alpha(\mathrm{pg} / \mathrm{mL})\end{array}$ & $\begin{array}{c}\text { IL- } \\
1 \beta(\mathrm{pg} / \mathrm{mL})\end{array}$ \\
\hline Normal & - & $100.8 \pm 9.7$ & $73.6 \pm 6.4$ \\
\hline $\begin{array}{l}\text { Negative } \\
\text { control }\end{array}$ & - & $165.4 \pm 14.2$ & $176.1 \pm 12.1$ \\
\hline Cernilton & 100 & $121.5 \pm 8.4$ & $114.5 \pm 11.7^{\prime \prime}$ \\
\hline PSA-L & 100 & $148.3 \pm 16.8$ & $152.7 \pm 15.8$ \\
\hline $\begin{array}{l}\text { PSA-M } \\
\text { PSA-H }\end{array}$ & $\begin{array}{l}200 \\
400 \\
\end{array}$ & $\begin{array}{c}134.7 \pm 10.2^{x} \\
116.5 \pm 9.3^{x \times} \\
\end{array}$ & $\begin{array}{c}117.5 \pm 10.7^{\text {x* }} \\
97.6 \pm 11.3^{\text {x }}\end{array}$ \\
\hline
\end{tabular}

Effect of ABBE on PGE 2 , COX-2, TGF- $\beta 1$ and CTGF

ABBE were assessed for their inhibitory activity on TGF- $\beta 1$ and CTGF production. As shown in Table 3, the level of TGF- $\beta 1$ was $72.6 \mathrm{pg} / \mathrm{ml}$ in sham group. Carrageenan caused significant increase in the level of TGF- $\beta 1$ in model group (< 0.01 ). After three weeks treatment of ABBE, the TGF- $\beta 1$ level was dose-dependently decreased $(p<0.01)$. Similarly, the level of CTGF was notably elevated in model group when compared with the sham group $(p<0.01)$. However, in ABBE extract treated group, the elevation was suppressed compared with the model group $(p<$ 0.01 ). Carrageenan treatment stimulated the level of COX-2 compared to sham group ( $p<$ 0.01). However, treatment of ABBE extract decreased the level of COX-2 $(p<0.01)$. The level of $P E G_{2}$ was increased in model group compared to sham group $(p<0.01)$. Oral treatment of ABBE extract at 200 and $400 \mathrm{mg} / \mathrm{kg}$ resulted in significant decrease of $P E G_{2}$ content when compared with model group $(p<0.01)$.

\section{DISCUSSION}

Achyranthes bidentata Blume. is traditionally used in Chinese medicine for treatment of prostatitis in China. In our study, the experimental chronic non-bacterial prostatitis was induced by carrageenan. The PI and PSA levels of model group rats were increased proved that prostatitis was established successfully by carrageenan. Then the potential therapeutic effect of ABBE in rats with carrageenan-induced prostatitis was evaluated. The whole results showed that $A B B E$ reduced $C O X-2$ and $P E G_{2}$ in model group rats. The TGF- $\beta 1$ and CTGF levels of ABBE group rats were significantly decreased while the inflammatory state of the prostate gland were alleviated. Thus, the administration of ABBE for 3 weeks significantly inhibited the development of chronic inflammation and fibrosis in prostatic tissue.

It is well accepted that the progression of CNP related to the complex network of cytokines, such as IL- $1 \beta$ and TNF- $\alpha[11,12]$. IL- $1 \beta$ is a pro-

inflammatory cytokine that induces the production of other inflammatory mediators involved with cellular recruitment, fever, acute

Table 3: Effect of ABBE on PGE 2 , COX-2, TGF- $\beta 1$ and CTGF levels (mean \pm SD, $n=10$ )

\begin{tabular}{|c|c|c|c|c|c|}
\hline Group & $\begin{array}{c}\text { Dose } \\
\text { (mg/kg) }\end{array}$ & $\begin{array}{c}\mathrm{PGE}_{2} \\
(\mathrm{pg} / \mathrm{mL})\end{array}$ & $\begin{array}{c}\text { COX-2 } \\
\text { (pg/mL) }\end{array}$ & $\begin{array}{l}\text { TGF- } \beta 1 \\
\text { (pg/mL) }\end{array}$ & $\begin{array}{c}\text { CTGF } \\
(\mathrm{pg} / \mathrm{mL})\end{array}$ \\
\hline Normal & & $67.8 \pm 3.6$ & $12.5 \pm 1.2$ & $72.6 \pm 4.1$ & $56.7 \pm 3.4$ \\
\hline -ve control & & $128.6 \pm 6.7$ & $31.5 \pm 3.4$ & $149.2 \pm 12.7$ & $121.4 \pm 5.8$ \\
\hline Cernilton & 100 & $87.4 \pm 5.9^{\prime \prime}$ & $16.2 \pm 2.8^{\prime}$ & $108.4 \pm 8.6$ & $87.4 \pm 6.1^{n}$ \\
\hline PSA-L & 100 & $105.6 \pm 4.8$ & $25.6 \pm 4.3$ & $125.3 \pm 9.6$ & $114.4 \pm 7.1$ \\
\hline PSA-M & 200 & $92.3 \pm 6.4^{\pi x}$ & $16.4 \pm 3.2^{x \times}$ & $110.5 \pm 7.6^{\pi x}$ & $92.4 \pm 8.4$ \\
\hline PSA-H & 400 & $79.2 \pm 4.5^{\pi \times}$ & $13.3 \pm 2.5^{* \pi}$ & $86.7 \pm 8.1^{\pi x}$ & $71.2 \pm 5.3^{\pi \pi}$ \\
\hline
\end{tabular}

-ve, negative; ${ }^{*} P<0.05, \quad{ }^{* *} p<0.01$ vs. model group 
phase protein release, increase of vascular permeability, and hyperalgesia [13]. TNF- $\alpha$, a pleiotropic pro-inflammatory cytokine, is rapidly produced by macrophages in response to tissue damage [14].

Previous studies have shown that activation of transcription factor NF-KB by TNF- $\alpha$ is one of the myriad actions of TNF- $\alpha$ that cause genes to generate potentially cell - damaging oxidative enzymes, as well as further release of TNF- $\alpha$, IL$1 \beta$ and other pro-inflammatory cytokines [15]. Cytokine - based therapies have been found to be useful in preventing progression of chronic prostatitis [16]. In the present study, the levels of TNF- $\alpha$ and IL-1 $\beta$ were increased in model group rats, whereas on treatment with ABBE extract at 200 or $400 \mathrm{mg} / \mathrm{kg}$, there were significant decreases in the cytokine levels. ABBE could suppress the release of pro-inflammatory mediators, which possess its anti-inflammatory activities. In this study, the COX-2 and $\mathrm{PEG}_{2}$ levels of rats were examined. It was found that in model group, the levels of those factors were enhanced. However, the increased levels of COX-2 and $P E G_{2}$ were reversed in treatment group of $A B B E$ extract. In addition, it was found that ABBE extract at the dose of $400 \mathrm{mg} / \mathrm{kg}$ significantly decreased $C O X-2$ and $P E G_{2}$ levels. Therefore, the anti-CNP effect of ABBE extract may be related to its anti-inflammatory properties.

TGF- $\beta$ is the most extensively studied molecule in fibrosis and stimulates the production of reactive oxygen species (ROS) in various types of cells, whereas ROS activate TGF- $\beta$ and mediate many of the fibrogenic effects of TGF- $\beta$ [17]. TGF- $\beta 1$ is known to induce fibroblast differentiation of into myofibroblast/smooth muscle cell in the human prostate [18]. In addition, other evidence suggests that pro-fibrotic effects of TGF- $\beta$ may be partly mediated by CTGF [19]. As another potent profibrotic factor, CTGF is implicated in fibroblast proliferation, cellular adhesion, angiogenesis, and extracellular matrix (ECM) synthesis [20]. Previous studies showed that CTGF promotes inflammatory response [21]. Chronic inflammatory response can result in pathological wound repair and the accumulation of permanent fibrotic scar tissue at the site of injury and this fibrosis may lead to a decrease in organ function and, in some cases, organ failure and death [22]. Summarily, another possible hypothesis could be given that the TGF$\beta 1 /$ CTGF pathway may also be involved in the CNP. The results indicate that ABBE could suppress the enhancement of the TGF- $\beta 1$ expression compared with model group rats. And $400 \mathrm{mg} / \mathrm{kg}$ of ABBE could decrease the TGF- $\beta 1$ level of model rats significantly, as well as CTGF level. ABBE regulated the CTGF signaling pathway following the TGF- $\beta 1$ stimulation. Thus, the anti-CNP effects of ABBE were also associated with the activity of anti-fibrotic.

\section{CONCLUSION}

The results of this study demonstrate that ABBE has a significant anti- inflammatory effect on chronic prostatitis in rats, and may thus be suitable for the treatment of chronic prostatitis. There is, however, a need for further investigation of its effectiveness.

\section{DECLARATIONS}

\section{Conflict of Interest}

No conflict of interest associated with this work.

\section{Contribution of Authors}

The authors declare that this work was done by the authors named in this article and all liabilities pertaining to claims relating to the content of this article will be borne by them.

\section{Open Access}

This is an Open Access article that uses a funding model which does not charge readers or their institutions for access and distributed under the terms of the Creative Commons Attribution License (http://creativecommons.org/licenses/by/ 4.0) and the Budapest Open Access Initiative (http://www.budapestopenaccessinitiative.org/rea d), which permit unrestricted use, distribution, and reproduction in any medium, provided the original work is properly credited.

\section{REFERENCES}

1. Motrich RD, Maccioni M, Molina R, Tissera A, Olmedo J, Riera CM, Rivero VE. Presence of INFgamma-secreting lymphocytes specific to prostate antigens in a group of chronic prostatitis patients. Clin Immunol 2005; 116: 149-157.

2. Werner WH. Anti-inflammatory therapies for chronic prostatitis. Eur Urol Supplements 2003; 2: 30-33.

3. Schaeffer AJ. Prostatitis: US perspective. Int $J$ Ant Agents 1999; 11: 205-211.

4. Krieger JN, Nyberg Jr, L, Nickel JC. NIH consensus definition and classification of prostatitis. J Am Med Assoc 1999; 282: 236-237.

5. Park SD, Lai YSH, Kim CHH. Immunopotentiating and antitumor activities of the purified polysaccharides from 
Achyranthes bidentata Blume.. Life Sci 2006; 73: 2611 2614.

6. Jung HW, Jin GZ, Kim SY. Neuroprotective effect of methanol extract of Achyranthes bidentata Blume. against 1-methyl-4-phenylpyridinium(MPP+)-induced apoptosis in PC-12 cells. Cell Bio. In.. 2005; 31: 954958.

7. Chen L,Di DL. Study on Antibacterial Effect in vitro of Achyranthes bidentata Blume. Lishizhen Med. Mate. Med. Res. 2006; 17: 759-760.

8. Xian YF, Mao QQ. Comparison on the anti-inflammatory effect of Achyranthes bidentata Blume. and Cortex Phellodendri Amurensis in 12-O-tetradecanoyl-phorbol13-acetate-induced ear edema in mice. $J$ Ethnopharmacol 2008; 134: 1426-1428.

9. European Commission [homepage on the internet]. Directive 2010/63/EU on the protection of animals used for scientific purposes [cited 2013 Jan 16]. Available from:http://ec.europa.eu/environment/chemicals/lab_ani mals/legislation_en.htm.

10. Chen RZ, Cui L, Guo YJ, Rong YM, Lu XH, Sun $M Y$, Zhang L, Tian JK. In vivo study of four preparative extracts of Clematis terniflora DC. for antinociceptive activity and anti-inflammatory activity in rat model of carrageenan-induced chronic non-bacterial prostatitis. J. Ethnopharmacol. 2011b; 134: 1018-1023.

11. Nadler RB, Koch AE, Calhoun EA, Campbell PL, Pruden $D L$, Bennett CL, Yarnold PR. IL-1beta and TNF-alpha in prostatic secretions are indicators in the evaluation of men with chronic prostatitis. J. Urol. 2000; 164: 214-218.

12. Tsunemori $H$, Sugimoto $M$, Xia Z, Taoka $R$, Oka $M$, Kakehi $Y$. Effect of the phytotherapeutic agent Eviprostat on inflammatory changes and cytokine production in a rat model of nonbacterial prostatitis. Urology 2011; 77: e1515-1517.
13. Dinarello CA. Interleukin-1, interleukin-1 receptors and interleukin-1 receptor antagonist. Int. Rev. Immunol. 1998; 16: 457-499.

14. Beutler B, Cerami A. The biology of cachectin/TNF-a primary mediator of the host response. Annu. Rev. Immunol. 1989; 7: 625-655.

15. Tahir $M$, Rehman $M U$, Lateef $A$, Khan R, Khan $A Q$, Qamar W, Ali F, O'Hamiza, O, Sultana S. Diosmin protects against ethanol-induced hepatic injury via alleviation of inflammation and regulation of TNF-alpha and NF-kappa B activation. Alcohol. 2013; 47: 131-139.

16. Lu BY, Cai HF, Huang, WS, Wu XQ, Luo YX, Liu L, Zhang, $Y$. Protective effect of bamboo shoot oil on experimental nonbacterial prostatitis in rats. Food. Chem. 2011; 124: 1017-1023.

17. Liu RM, Gaston KA. Oxidative stress and glutathione in TGF-beta-mediated fibrogenesis. Free. Radic. Biol. Med. 2010; 48: 1-15.

18. Untergasser G, Gander R, Lilg C, Lepperdinger G, Plas E, Berger $P$. Profiling molecular targets of TGF-beta1 in prostate fibroblast-to-myofibroblast transdifferentiation. Mech. Ageing. Dev. 2005; 126: 59-69.

19. Leask, A, Abraham, DJ. TGF-beta signaling and the fibrotic response. FASEB J. 2004; 18: 816-827.

20. Lau LF, Lam SC. The CCN family of angiogenic regulators: the integrin connection. Exp. Cell. Res. 1999; 248: 44-57.

21. Kular L, Pakradouni J, Kitabgi, P, Laurent M, Martinerie C. The CCN family: a new class of inflammation modulators? Biochimie. 2011; 93: 377-388.

22. Borthwick, LA, Wynn TA, Fisher AJ. Cytokine mediated tissue fibrosis. Biochim. Biophys. Acta. 2013; 1832: 1049-1060. 